\title{
Candlenut Business Development Strategy (Aleurites mollucana L.Wild) in KPHL Selayar
}

\author{
Andi Sartina Ningsih ${ }^{* 1}$, Baharuddin ${ }^{1}$, Daud Malamassam ${ }^{1}$ \\ *Faculty of Forestry, Hasanuddin University, Jl. Perintis Kemerdekaan Km. 10 Tamalanrea, Makassar, \\ Sulawesi Selatan, Indonesia
}

\begin{abstract}
The use of candlenut (Aleurites Mollucana., L. Wild) as a non-timber forest product is expected to be a excellent product in the KPHL of Selayar in line with the designation of the area as a Protected Forest Management Unit (KPHL). Candlenut is a non-timber forest product (NTFP) which has great economic potential, but in the management of the candlenut business in the KPHL Selayar has not been able to be optimally developed as the scale of the use of candlenut remain low and the business model conducted appears to be traditional. The study aimed to analyze and identify internal and external factors in formulating the right strategic priorities in the development of the candlenut business at KPHL Selayar. The method employed was a combination of SWOT and AHP by describing internal and external factors, then tabulating it so that it would formulate a priority of strategic choices. The results showed that among the four SWOT groups namely Strengths (S), Weaknesses (W), Opportunities $(O)$ and Threats $(T)$ which became the priority of the SWOT group which had a great influence on the development of the candlenut business, the Strength $(S)$ group with a value of 10.55. Based on the formulated results of the candlenut business development strategy, it was concluded that the priority strategy to be implemented was the S-O 3 strategy, namely increasing the candlenut business collaboration to expand the marketing network with a priority value of 0.107 .
\end{abstract}

Keywords: Strategy, Candlenut, SWOT Analysis, AHP

\section{INTRODUCTION}

The Law of Number 41 of 1999 concerning Forestry mandates that forest management be carried out at the management unit level, namely the smallest forest management unit according to its main function and designation, which can be managed efficiently and sustainably [1]. Academics, bureaucracies, and practitioners as well as most stakeholders in the forestry sector believe that forest management at the site level, or the socalled Forest Management Unit (KPH), is a system that can better guarantee the realization of the sustainability of forest functions and benefits, both from the economic aspect, ecological and social [2].

The Selayar Forest Management Unit (KPH) is one of the forest area managers at the site level whose working area is in the Selayar Islands Regency, South Sulawesi Province, and has been established since 2011 through the Decree of the Appointment of the Minister of Forestry Number SK.88/Menhut-II/2011 dated 9 March 2011 with a forest area of approximately $+18,647$ hectares which is divided into protection and production functions. In the forest area management plan that has been prepared by the Head of the Selayar Forest Management Unit and ratified by the Director of the Protected Forest Management Unit of the Ministry of Environment and Forestry, the division of forest area management blocks has been determined as the basis for implementing programs and activities in the Selayar KPHL. The division of forest area management blocks that become certain areas of the Selayar KPHL consists of Core blocks, NTFP utilization blocks, environmental services, and nature tourism, plantation forest utilization blocks, empowerment blocks, and protection blocks [3].

Environmental service utilization blocks (NTFP) are designated as non-timber forest product concession areas by communities that have been dependent on natural resources for generations. NTFP management can fulfill various livelihood functions and provide consumptive goods directly [4]. Furthermore, [5] stated that currently, NTFP products are an income as well as direct income for meeting the needs of many households in Indonesia. The economic value of NTFPs is estimated to reach $90 \%$ of the total economic value that can be generated from forest ecosystems. Currently, non-timber products and environmental services are being 
DOI: $\underline{10.51386 / 25815946 / i j s m s-v 4 i 3 p 121}$

Volume: 4 Issue: 3

May to June 2021

www.ijsmsjournal.org

proclaimed to become the backbone of national forestry development, the potential for NTFP production is estimated to be much greater than the production of logs, but until now these potentials have not been exposed massively due to the attention of all kinds of stakeholders. still relying on wood. If it is addressed, the contribution [to the country's foreign exchange] from NTFPs and Environmental Services is very large [6].

The use of non-timber forest products at KPHL Selayar is in the form of collecting candlenuts. Based on the results of the preliminary study, data on potential candlenut forest products in the Selayar KPHL in 2019 was 141,100 trees with a concession area of 2,016 hectares. Kemiri (Aleurites mollucana L, Willd) as one of the trees producing NTFP products have been widely used by the community around the Selayar KPHL forest area, especially in the Bontosikuyu sub-district, Selayar Islands Regency, which has been designated as a certain area of NTFP utilization blocks. Candlenut plants by the community in Bontosikuyu District, Kab. The Selayar Islands have a strategic value because they are one of the economic supports for farmer households throughout the year and have been cultivated for generations. The existence of candlenut as a non-timber forest product is expected to be a superior product in Selayar KPHL in line with the area designated as a Protected Forest Management Unit (KPHL). Therefore, candlenut should be considered as a source of economic contribution to the forestry sector both in the short and long term in South Sulawesi, especially in KPHL Selayar [3].

The issues that emerged in realizing the exploitation of candlenut NTFPs at KPHL Selayar is that the community around the area is active in picking candlenut fruit in the forest area but has not mastered the candlenut processing technology, the scale of utilization is still low, the use of candlenut NTFPs is still based on the collection and not based on cultivation so that the sustainability of the results NTFPs are not guaranteed.

Based on the description of the problems above, it is necessary to make efforts to formulate a strategy for developing candlenut business at KPHL Selayar, identifying internal and external factors which influence the development of candlenut NTFP business to run well, directed and sustainable, to realize management efforts sustainable productive and sustainable forest in the Selayar KPHL, so that the economic, social and environmental benefits of candlenut management can be encountered by all parties.

\section{A. Study Site}

\section{RESEARCH METHODS}

The research was conducted from October - November 2020. The research location was located in the Limited Production Forest Area, Bontosikuyu District, the regency of Selayar Island. According to data from the Central Bureau of Statistics of the Selayar Islands (2019), the potential for candlenut trees in the KPHL Selayar was as many as 141,100 trees with a utilization area of \pm 2,016 ha of the Bontosikuyu District Limited Production Forest Area of $\pm 5,772.51 \mathrm{Ha}$.

\section{B. Data Collection Technique}

The stages of research activities were carried out through direct observation starting from the activities of collecting the candlenut fruit, the drying process, the process of peeling the hazelnut ingredients to the marketing process. In-depth interviews with stakeholders involved in the candlenut business employed a questionnaire. The stakeholders involved included several experts from candlenut farmers who had more experience related to candlenut management, government experts who were considered to influence the management and development of the candlenut business, and academic experts who understood the right strategy in the management and development of the candlenut business in terms of theory. The questionnaire used was a closed questionnaire in which the respondents only answered the questionnaire that had been determined to provide a comparative value of each alternative criteria. A literature study was also carried out through the collection of secondary data that supported this research. The study used qualitative and quantitative methods. The population in this study were farmers who process candlenuts in the Limited Production Forest Area, Bontosikuyu district, the regency of Selayar Island. In this study, the sample used was the purposive sampling technique, where the determination of the sample was based on certain considerations. Each subject taken from the population was chosen intentionally with the aim and consideration that the respondent had been doing the collection and processing of candlenut ingredients for a long time and had adequate information in fulfilling the data needs. 
DOI: $\underline{10.51386 / 25815946 / \mathrm{ijsms}-\mathrm{v} 4 \mathrm{i} 3 \mathrm{p} 121}$

Volume: 4 Issue: 3

May to June 2021

www.ijsmsjournal.org

\section{Data Analysis}

The data analysis used was descriptive, SWOT analysis and continued with hierarchical analysis (AHP). Determination of criteria and indicators used to formulate several alternative strategies for developing candlenut business was based on the Regulation of the Minister of Forestry of the Republic of Indonesia Number: P.19 / Menhut / II / 2009 concerning the Strategy for Development of National Non-Timber Forest Products and Regulation of the Minister of Forestry of the Republic of Indonesia No. P.21 / Menhut / II / 2009 concerning Criteria and Indicators for Determining Preferred Types of Non-Timber Forest Products, which consist of economic, biophysical and environmental, institutional, social and technological criteria. The data obtained were collected, processed employing data tabulation, and then analyzed according to the research objectives. The data obtained is then processed and analyzed by SWOT analysis to evaluate internal factors that become strengths and weaknesses as well as external factors that become opportunities and threats that may occur in the development of the candlenut business at KPHL Selayar and followed by a hierarchy of analysis (AHP) to select strategic priorities that can be used in the development of the candlenut business at KPHL Selayar.

\section{RESULTS AND DISCUSSION}

\section{A. The formulation of the Kemiri Business Development Strategy at KPHL Selayar}

The candlenut business development strategy at KPHL Selayar is directed by using the SWOT and AHP analysis formulations. SWOT analysis is started with identifying and classifying various internal factors (strengths and weaknesses) and external factors (opportunities and threats) systematically to be included in the analysis. Calculates the value of strengths, weaknesses, opportunities, and threats then calculates the SWOT factor and then calculates the priority of the SWOT group by comparing internal factors (strengths and weaknesses) and external factors (opportunities and threats) to formulate the priority value of the candlenut business development strategy at KPHL Selayar.

The identification and formulation of an analysis of the conditions encountered in the community are about the development of the candlenut business at the research location including internal and external factors based on the results of interviews as follows:

1. Analysis of internal factors

The process of identifying and formulating the value of the strength and weakness factors:

Table 1. The Score of the Internal factor

\begin{tabular}{|c|c|l|c|}
\hline Code & Indicator & \multicolumn{1}{|c|}{ Statement } & Rating \\
\hline \multirow{4}{*}{ S } & S1 & There has been an increase in product value-added & 3 \\
\cline { 2 - 4 } & S2 & Not listed in the CITEX Appendix index & 5 \\
\cline { 2 - 4 } & S3 & Accessibility is easy & 3 \\
\cline { 2 - 4 } & S4 & High community involvement & 4 \\
\cline { 2 - 4 } & S5 & There is a candlenut business collaboration & 5 \\
\hline \multirow{6}{*}{ W } & W1 & Marketing only involves the community and collectors & 4 \\
\cline { 2 - 4 } & W2 & Little plant potential & 5 \\
\cline { 2 - 4 } & W3 & Less plant spread & 5 \\
\cline { 2 - 4 } & W4 & Candlenut production still comes from natural stands & 5 \\
\cline { 2 - 4 } & W6 & No business group & 5 \\
\cline { 2 - 4 } & W7 & No business group association & 5 \\
\cline { 2 - 4 } & W8 & Standard of Indonesia (Standar Nasional Indonesia) & 5 \\
\cline { 2 - 4 } & W9 & Mastery of cultivation technology remains low & 5 \\
\cline { 2 - 4 } & W10 & The community has not mastered the technology of processing results & 5 \\
\hline
\end{tabular}

Source: Primary Data having been processed

After the internal assessment was carried out, a matrix analysis was performed based on a comparison of each chosen expert. The selected experts were based on the parties involved in the utilization and processing of candlenuts and had adequate information regarding the development of the candlenut business at KPHL Selayar. The experts were given a form according to the statement in the table in each SWOT group to 
DOI: $\underline{10.51386 / 25815946 / \mathrm{ijsms}-\mathrm{v} 4 \mathrm{i} 3 \mathrm{p} 121}$

Volume: 4 Issue: 3

May to June 2021

www.ijsmsjournal.org

give scores to the form to gain expert judgments. The expert judgment was carried out to determine the factors which were the most priority dimensions in the SWOT group. The mixed results of the combined strength factors of all experts can be seen in Table 2 .

Table 2. AHP Pairwise Combined Matrix Strength Factor

\begin{tabular}{|c|c|c|c|c|c|}
\hline Factors & S1 & S2 & S3 & S4 & S5 \\
\hline S1 & 1,00 & 0,24 & 1,40 & 2,12 & 1,89 \\
\hline S2 & 4,09 & 1,00 & 3,00 & 3,61 & 3,32 \\
\hline S3 & 0,71 & 0,33 & 1,00 & 1,41 & 1,12 \\
\hline S4 & 0,47 & 0,27 & 0,70 & 1,00 & 1,00 \\
\hline S5 & 0,52 & 0,30 & 0,89 & 1,00 & 1,00 \\
\hline Total & 6,79 & 2,14 & 6,99 & 9,14 & 8,33 \\
\hline
\end{tabular}

Source: Primary data having been processed

Based on Table 2, the combined pairwise comparison matrix of the assessment test results of all experts from 5 (five) strength factor questions obtained an interval of values from the lowest 2.14 (S2 factor, which is not listed in the CITEX index) and the highest 9.14 (S4 factor, which is high community involvement) if added up from top to bottom.

The result shows that the S4 factor, called the high community involvement, is the most influential loading factor in the strategy of developing the candlenut business at KPHL Selayar where the high involvement of the community in the utilization of non-timber forest products, can help from the economic aspect, the community gets a livelihood without damaging the forest The high interest and involvement of the community is a factor that influences the potential development of NTFPs because they will tend to increase business results in their location so that it is expected to increase people's income [7]. As for the S2 factor, it is not listed in the CITEX Appendix index where the conservation status of the candlenut plant does not include protected plants or is not close to extinction. NTFP species that are not listed in the CITEX Appendix index can be used more freely and traded [8].

In the next process, to see the results of all the experts who have been given the pairwise comparison matrix form according to the statements in each SWOT group, then see the results of the paired combined matrix on the weakness factors of all the experts. The pairwise combined matrix of the weak loading factors is presented in Table 3.

Table 3. AHP Pairwise Combined Matrix Weakness Factors

\begin{tabular}{|c|c|c|c|c|c|c|c|c|c|c|}
\hline Factor & W1 & W2 & W3 & W4 & W5 & W6 & W7 & W8 & W9 & W10 \\
\hline W1 & 1,00 & 0,93 & 0,83 & 1,60 & 0,74 & 0,42 & 0,83 & 1,22 & 1,37 & 1,65 \\
\hline W2 & 1,07 & 1,00 & 1,00 & 1,70 & 0,89 & 0,47 & 0,95 & 1,12 & 1,59 & 2,00 \\
\hline W3 & 1,20 & 1,00 & 1,00 & 1,78 & 0,89 & 0,47 & 1,00 & 1,12 & 1,41 & 1,59 \\
\hline W4 & 0,62 & 0,59 & 0,56 & 1,00 & 0,50 & 0,31 & 0,59 & 0,70 & 0,45 & 0,95 \\
\hline W5 & 1,34 & 1,12 & 1,12 & 2,00 & 1,00 & 0,52 & 1,12 & 1,35 & 1,61 & 1,91 \\
\hline W6 & 2,38 & 2,13 & 2,13 & 3,17 & 1,91 & 1,00 & 2,00 & 2,40 & 2,57 & 2,52 \\
\hline W7 & 1,20 & 1,05 & 1,00 & 1,69 & 0,89 & 0,50 & 1,00 & 1,26 & 1,91 & 2,03 \\
\hline W8 & 0,81 & 0,89 & 0,89 & 1,41 & 0,74 & 0,41 & 0,79 & 1,00 & 1,41 & 1,78 \\
\hline W9 & 0,72 & 0,62 & 0,70 & 1,18 & 0,62 & 0,39 & 0,52 & 0,70 & 1,00 & 1,18 \\
\hline W10 & 0,60 & 0,50 & 0,62 & 1,05 & 0,52 & 0,40 & 0,49 & 0,56 & 0,47 & 1,00 \\
\hline Total & 10,94 & 9,83 & 9,85 & 16,58 & 8,70 & 4,89 & 9,29 & 11,43 & 13,79 & 16,61 \\
\hline
\end{tabular}

Source: Primary data having been processed

Based on Table 3, the combined matrix of pairwise comparisons of expert assessment test results from 10 questions of weakness factors resulted in the lowest score of 4.89 for the W6 factor (no business group association) and the highest score of 16.61, namely the W10 factor (the community had not mastered the result processing technology). 
DOI: $\underline{10.51386 / 25815946 / i j s m s-v 4 i 3 p 121}$

Volume: 4 Issue: 3

May to June 2021

www.ijssmsjournal.org

The results of the assessment test for the W6 factor that there is no business group association in question, namely the existence of business group associations shows the level of interest of business groups forming associations to increase competitiveness and can help product marketing. As for W10, the community has not mastered the technology of processing results where candlenut farmers at KPHL Selayar still use traditional tools in processing candlenuts even though some farmers have candlenut crusher machines but people prefer to use traditional manual crushing tools made of rattan. The post-harvest process by farmers who still use traditional tools and have not utilized more modern technology can affect the quality and quantity of candlenut products so that the prices can be lower [9].

The results of the combined matrix of pairwise comparisons of each factor and group show the dominant and non-dominant values of factors and groups. It is in line with the approach using a matrix of reflection of the multiple aspects which exist in priority, namely dominating and being dominated according to the method used [10].

2. Analysis of external factors

The process of identifying and formulating the value of opportunity and threat factors:

Table 4. External factor score

\begin{tabular}{|c|c|l|c|}
\hline Code & Indicator & & Rating \\
\hline \multirow{4}{*}{} & O1 & High export value & 5 \\
\cline { 2 - 4 } & O2 & High domestic trade value & 5 \\
\cline { 2 - 4 } & O3 & Marketing in the national and local scope & 2 \\
\cline { 2 - 4 } & O4 & There is a demand from the international market & 4 \\
\cline { 2 - 4 } & O5 & Some rules regulate the pattern of cooperation in the use of NTFPs & 5 \\
\cline { 2 - 4 } & O6 & There is support from the institution & 5 \\
\hline \multirow{4}{*}{ T } & T1 & No investment in business & 4 \\
\cline { 2 - 4 } & T2 & $\begin{array}{l}\text { The high interest of the community to change the commodity being } \\
\text { cultivated }\end{array}$ & 4 \\
\cline { 2 - 4 } & T3 & Lack of interest in a productive workforce & 5 \\
\cline { 2 - 4 } & T4 & $\begin{array}{l}\text { Lack of synergy of stakeholders to work together in the development } \\
\text { of candlenut plants }\end{array}$ & 5 \\
\hline
\end{tabular}

Sources: Primary data having been processed

From 10 item statements for external factors, a pairwise comparison analysis was then carried out on each specified expert. Experts are given a pairwise comparison matrix form according to 10 questions in each SWOT group and produce an expert assessment test. The assessment test is carried out to know the factors that are the most priority elements in the SWOT group. The pairwise comparison test is an assessment of decisionmaking by assessing the level of importance of an element with other elements in the hierarchy. The results of the combined pairwise comparison matrix of opportunity factors from all experts can be seen in Table 5.

Table 5. AHP Pairwise Combined Matrix Probability Factor

\begin{tabular}{|c|c|c|c|c|c|c|}
\hline Faktor & O1 & O2 & O3 & O4 & O5 & O6 \\
\hline O1 & 1,00 & 2,01 & 1,98 & 1,44 & 2,47 & 2,37 \\
\hline O2 & 0,50 & 1,00 & 0,89 & 0,75 & 1,51 & 1,04 \\
\hline O3 & 0,51 & 1,12 & 1,00 & 0,66 & 1,34 & 1,34 \\
\hline O4 & 0,69 & 1,34 & 1,51 & 1,00 & 1,84 & 1,61 \\
\hline O5 & 0,40 & 0,66 & 0,75 & 0,54 & 1,00 & 1,00 \\
\hline O6 & 0,42 & 0,96 & 0,75 & 0,62 & 1,00 & 1,00 \\
\hline Total & 3,52 & 7,09 & 6,88 & 5,01 & 9,16 & 8,36 \\
\hline
\end{tabular}

Sources: Primary data having been processed

The opportunity factor is an analysis of external factors used to see the influence of these factors on the development of the candlenut business at KPHL Selayar. Based on the results of the calculation of the combined pairwise comparison matrix on the opportunity factor $(\mathrm{O})$ which has been assessed, it can be seen that the lowest value is the $\mathrm{O} 1$ factor 3.52 (high export value) and the highest in the $\mathrm{O5}$ factor 9.16 (rules are governing the pattern Cooperation in the use of NTFPs). 
DOI: $\underline{10.51386 / 25815946 / \mathrm{ijsms}-\mathrm{v} 4 \mathrm{i} 3 \mathrm{p} 121}$

Volume: 4 Issue: 3

May to June 2021

www.ijssmsjournal.org

O1 factor explains that the value of exports is high where the value of export trade is the foreign exchange value of NTFPs obtained from each district which is measured in one year expressed in US dollars/year [8]. Based on the results of interviews with the Department of Industry and Trade in the Selayar Islands Regency, the value of candlenut exports can be calculated to be more than the US \$ 1 million per year. As for the results of the assessment on factor O5, it explains that the existence of rules governing the pattern of Cooperation in the use of NTFPs shows that the use of these commodities has more value because they already have a clear legal basis and rules for further development, especially if the regulations in question are related to trade or marketing [8].

The next process to see the results of the analysis from all experts who have been given a combined matrix form of pairwise comparisons on the threat factor (T) can be seen in Table 6.

Table 6. AHP Paired Concatenated Matrix Threat Factor

\begin{tabular}{|c|c|c|c|c|}
\hline Factor & T1 & T2 & T3 & T4 \\
\hline T1 & 1,00 & 3,09 & 1,82 & 3,22 \\
\hline T2 & 0,32 & 1,00 & 0,59 & 1,12 \\
\hline T3 & 0,55 & 1,69 & 1,00 & 1,69 \\
\hline T4 & 0,31 & 0,89 & 0,59 & 1,00 \\
\hline Total & 2,18 & 6,67 & 4,00 & 7,03 \\
\hline
\end{tabular}

Source: Primary data having been processed

Based on Table 6, the combined pairwise comparison matrix results from the assessment of all experts from 6 threat factor of item statement from the lowest value of 2.18 on the T1 factor (no investment in the business) and the highest value of 7.03 on the T4 factor (no synergy of stakeholders to work together in the development of candlenut plants). Threat factors are also external factors that can affect the development of the candlenut business at KPHL Selayar.

Noticing that the candlenut business in KPHL Selayar is still being managed by the farming community around the forest area, there has been no business investment. Business investment shows that through investment, these commodities make a real contribution to economic growth [8] this is in line with [11] which asserts that to improve the economy, the determinants of agricultural production are if the government and private individual investors give the necessary attention to diversifying the production base and export. It refers to the results of the T1 assessment, namely that no investment in the business is a threat factor that affects the development of the candlenut business at KPHL Selayar. Meanwhile, based on the results of the T4 factor assessment which states that there is no synergy of stakeholders to work together in the development of the candlenut plant, it explains that stakeholders in the Selayar Islands Regency have each business development program with different commodities so that the implementation in the community overlaps even there are people who cut down their candlenut trees to convert them into nutmeg, pouring, onions, and other crops, whereas if each stakeholder synergizes with each other, it can be done using an agroforestry pattern.

After the experts analysed the value of each factor, then the pairwise comparison matrix can be seen to test the value of the SWOT group which is the second hierarchy above the SWOT factor as the third hierarchy. The results of the combined SWOT group pairwise comparison matrix from all experts can be seen in Table 7

Table 7. Combined Matrix of AHP Pairwise Comparison Between SWOT Groups.

\begin{tabular}{|c|c|c|c|c|}
\hline Group & $\mathrm{S}$ & $\mathrm{W}$ & $\mathrm{O}$ & $\mathrm{T}$ \\
\hline $\mathrm{S}$ & 1,00 & 0,21 & 0,66 & 0,30 \\
\hline $\mathrm{W}$ & 4,67 & 1,00 & 2,08 & 1,61 \\
\hline $\mathrm{O}$ & 1,51 & 0,48 & 1,00 & 0,57 \\
\hline $\mathrm{T}$ & 3,37 & 0,62 & 1,76 & 1,00 \\
\hline Total & 10,55 & 2,32 & 5,50 & 3,47 \\
\hline
\end{tabular}

Based on Table 7, it can be seen that the results of the assessment of all experts from the 4 SWOT groups obtained a score of $2.32-10.55$. The lowest value in the Weakness group (W) and the highest value in 
DOI: $\underline{10.51386 / 25815946 / \mathrm{ijsms}-\mathrm{v} 4 \mathrm{i} 3 \mathrm{p} 121}$

Volume: 4 Issue: 3

May to June 2021

www.ijsmsjournal.org

the Strength group (S), if it is sorted from top to bottom. It can be concluded that the strength group is an influential component and the weakness group can be minimized in the development of the candlenut business at KPHL Selayar.

\section{B. Priority and Consistency Ratio of Group Comparison and SWOT Factors}

The local priority for each SWOT factor is obtained from the average normalized value of the combined matrix multiplied by the total value of the combined matrix. The next step is to determine the priority of each SWOT factor and see the consistency of the ratio of the value of the expert assessment test results.

Table 8. Priority Matrix and Consistency Ratio of Group Comparison and SWOT Factors

\begin{tabular}{|c|c|c|c|c|c|}
\hline Group & Factor & Priority & $\begin{array}{l}\text { Consistency } \\
\text { Ratio (CR) }\end{array}$ & $\begin{array}{c}\text { Local } \\
\text { Priority }\end{array}$ & $\begin{array}{c}\text { Global } \\
\text { Priority }\end{array}$ \\
\hline \multirow{5}{*}{ Strength } & \multirow{5}{*}{0.472} & S1 & \multirow{5}{*}{0.02000} & 0.171 & 0.080712 \\
\hline & & S2 & & 0.067 & 0.031624 \\
\hline & & S3 & & 0.214 & 0.101008 \\
\hline & & S4 & & 0.286 & 0.134992 \\
\hline & & S5 & & 0.262 & 0.123664 \\
\hline \multirow{10}{*}{ Weakness } & \multirow{10}{*}{0.108} & W1 & \multirow{10}{*}{0.00253} & 0.096 & 0.010368 \\
\hline & & $\mathrm{W} 2$ & & 0.086 & 0.009288 \\
\hline & & W3 & & 0.087 & 0.009396 \\
\hline & & W4 & & 0.148 & 0.015984 \\
\hline & & W5 & & 0.076 & 0.008208 \\
\hline & & W6 & & 0.044 & 0.004752 \\
\hline & & W7 & & 0.081 & 0.008748 \\
\hline & & W8 & & 0.100 & 0.010800 \\
\hline & & W9 & & 0.130 & 0.014040 \\
\hline & & W10 & & 0.151 & 0.016308 \\
\hline \multirow{6}{*}{ Opportunity } & \multirow{6}{*}{0.267} & O1 & \multirow{6}{*}{0.00211} & 0.088 & 0.023496 \\
\hline & & $\mathrm{O} 2$ & & 0.177 & 0.047259 \\
\hline & & $\mathrm{O} 3$ & & 0.169 & 0.045123 \\
\hline & & $\mathrm{O} 4$ & & 0.125 & 0.033375 \\
\hline & & O5 & & 0.230 & 0.061410 \\
\hline & & O6 & & 0.210 & 0.056070 \\
\hline \multirow{4}{*}{ Threats } & \multirow{4}{*}{0.154} & $\mathrm{~T} 1$ & \multirow{4}{*}{0.00047} & 0.109 & 0.016786 \\
\hline & & $\mathrm{T} 2$ & & 0.333 & 0.051282 \\
\hline & & T3 & & 0.202 & 0.031108 \\
\hline & & T5 & & 0.356 & 0.054824 \\
\hline
\end{tabular}

Sources: Primary data having been processed

Based on Table 8, the normalization of the combined matrix of pairwise comparisons in each SWOT group is on average consistent. It is because it does not exceed the number 1.00 according to the formula where if $<0$, it is considered an error, if $=0$, it is considered very consistent if $>0-1$, then it is considered consistent, and if $>$ 1 , it is considered inconsistent. If it does not meet these requirements, then the assessment must be repeated in the AHP method.

In this study, each consistency ratio value did not exceed the number 1 . This is following the statement [12] that the expected consistency is near perfect to produce a valid decision. Although it is difficult to achieve perfection, the consistency ratio is expected to be less than 1 [13]. 


\section{The formulation of the Candlenut Business Development Strategy}

Factor priority values, group priority values, and global priority values can be used to determine the candlenut business development strategy at KPHL Selayar. Then, to formulate a candlenut business development strategy, it can be determined qualitatively directly derived from the values obtained, then selecting four of the highest value of the priority of each SWOT factor to be placed in the SWOT matrix to implement the strategy to be taken, which consists of SO, ST, WO, and WT strategies. The matrix to formulate the candlenut business development strategy can be seen in Figure 1.

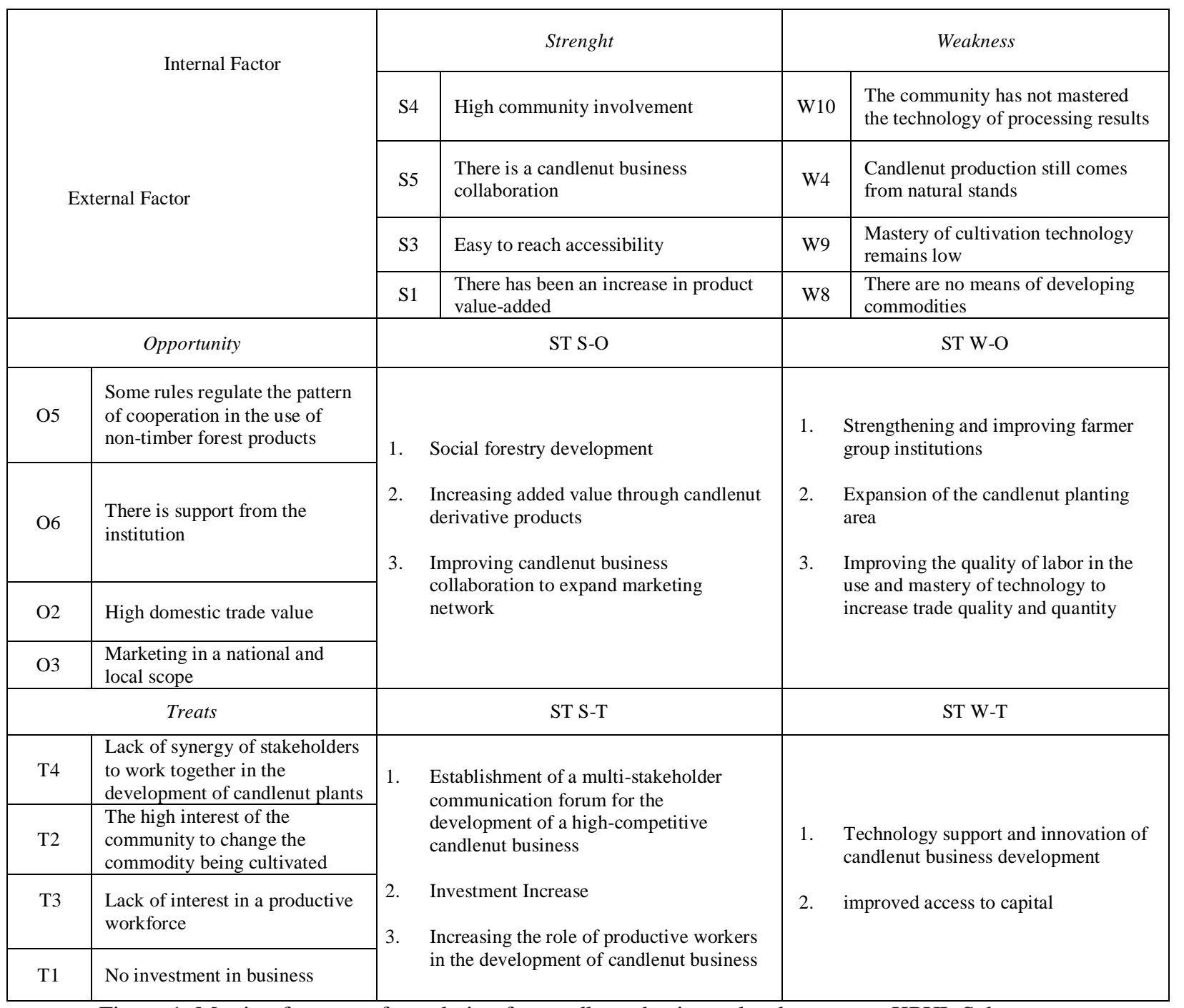

Figure 1. Matrix of strategy formulation for candlenut business development at KPHL Selayar

Based on Figure 1, several S-O strategies have been formulated in which this strategy utilizes all strengths to seize and take advantage of opportunities that may be achieved. The S-O strategies that have been formulated are 1). Acceleration of social forestry development process, 2). Increasing added value through candlenut derivative products, and 3). Increase the collaboration of candlenut business to expand the marketing network.

The next strategy formulation is the ST strategy, which is a strategy that is formulated using the strengths possessed to overcome threats that are likely to be faced. The formulated ST strategy is 1). Establishment of a multi-stakeholder communication forum for the development of a high-competitive candlenut business, 2). Increased Investment, and 3). Increasing the role of productive workers in the development of candlenut business. 
The formulation of the W-O strategy is a strategy that is formulated based on efforts to minimize weaknesses in seizing opportunities. The strategies formulated are 1). Strengthening and improving farmer group institutions, 2). Expansion of the candlenut planting area, and 3). Improving the quality of the workforce in the use and mastery of technology to increase the quality of trade.

The next strategy formulation is the W-T strategy which is formulated based on efforts to minimize existing weaknesses to avoid threats. The strategies formulated are 1). Technology support and innovation of candlenut business development, and 2). Improved access to capital.

\section{Priority of Candlenut Business Development Strategy}

The formulation of a candlenut business development strategy should be well formulated. It is important to select a strategy that becomes a priority in implementing a strategic plan for every increase in candlenut productivity. The implementation of the candlenut business development strategy is expected to be carried out in a more planned and focused manner so that the candlenut business development can run well, directed, and sustainable to realize sustainable and productive forest management efforts. The strategic priority in the development of the candlenut business can be seen in Figure 2.

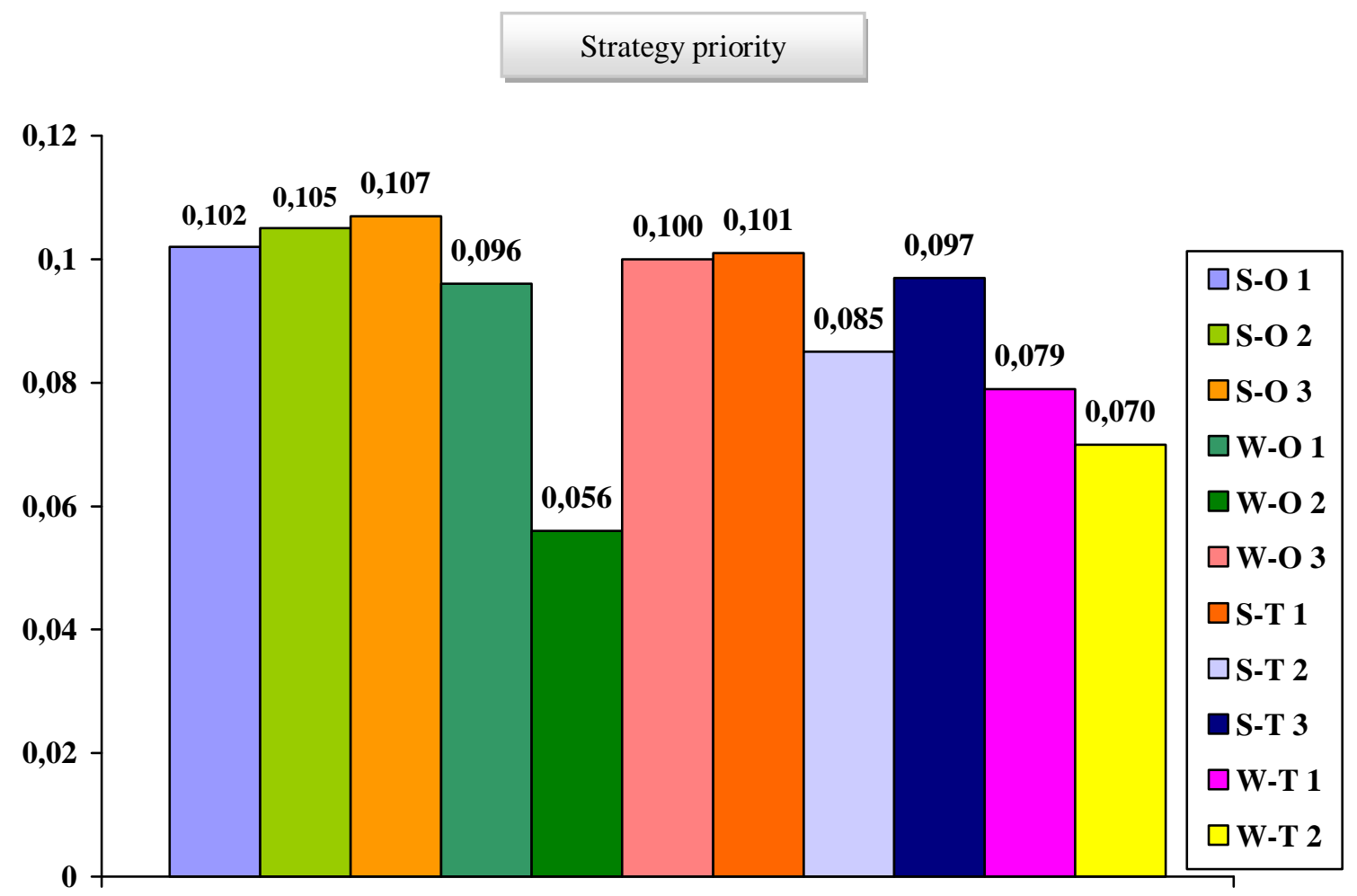

STRATEGY

Figure 2. The priority score of the candlenut business development strategy at KPHL Selayar

The results of the analysis and the highest calculation of the overall strategy formulation that has the first highest priority value are the SO 3 strategy with a value of 0.107 (Increasing the collaboration of candlenut business to expand the marketing network), the second-highest strategy is SO 2 with a value of 0.105 (Increasing added value through candlenut derivative products ) and the third-highest strategy is SO 1 strategy with a value of 0.102 (Social Forestry Development). From the results of the priority value of the candlenut business development strategy at KPHL Selayar, it can be seen that almost all strategies influence business development, but it is concluded that the chosen strategy is the strategy that has the highest priority value, namely the S-O3 strategy to increase the collaboration of candlenut business to expand the marketing network. 
The whole strategy formulated does not rule out the possibility that all of these strategies are very important and can be applied in the development of the candlenut business at KPHL Selayar. This is in line with [14] which states that strategic priorities can change due to changes in internal and external conditions. If the strategic priorities change following the changes that occur, the resulting alternative strategies can still change following the changes that occur. This happens if a sensitivity analysis is carried out on the strategy.

\section{IV.CONCLUSIONS}

Derived from the results of research and discussion, several conclusions can be obtained, including:

1. Based on the identification of the SWOT factors in the development of the candlenut business, the internal factors that become the priority in the Strength group are i). High community involvement $(0.286)$, ii). There is a candlenut business collaboration (0.262), iii). Accessibility is easy to reach (0.214), and iv). There has been an increase in the added value of the product $(0.171)$. The priority factors in the Weakness group are i). The community has not mastered the technology of processing results $(0.151)$, ii). Candlenut production still comes from natural stands $(0.148)$, iii). Mastery of cultivation technology is still low (0.130), and iv). There is no commodity development facility (0.100).

2. The priority external factors in the Opportunity group are i). Rules are governing the pattern of cooperation in the use of non-timber forest products (NTFPs) (0.230), ii). There is support from the institution (0.210), iii). The value of domestic trade is high (0.177), and iv). Marketing in the national and local scope (0.169).

3. The right alternative strategy in developing the candlenut business is the S-O 3 strategy, namely (Improving the collaboration of candlenut business to expand the marketing network) with a priority value of 0.107 . Furthermore, the second-highest strategy is the S-O 2 with a value of 0.105 (Increasing added value through candlenut derivative products) and the third-highest strategy is the S-O 1 strategy with a value of 0.102 (Social Forestry Development). Government cooperation, human resources, technology utilization, and marketing are aspects that are very supportive in the development of small businesses. In particular, the development of the candlenut business at KPHL Selayar greatly affects the level of income and improves the welfare of the community.

\section{REFERENCES}

[1] Tajuddin T, Supratman S, Darmawan S, Yusran Y. 2019. Bridging Social Forestry and Forest Management Unit : Justaposing policy imaginaries with implementation practices in a case from Sulawesi. J. Forest and Society. DOI : 10.24259 / FS.V3T1.6049

[2] Kartodihardjo, H., Nugroho, B., \& Putro, H. R. 2011. Pembangunan Kesatuan Pengelolaan Hutan (KPH) ; Konsep, Peraturan Perundangan dan Implementasi. Direktorat Wilayah Pengelolaan dan Penyiapan Areal Pemanfaatan Kawasan Hutan, Direktorat Jenderal Planologi Kehutanan.

[3] KPHL Unit XVI Selayar. 2019. KPHL Unit XVI Long Term Forest Management Plan (RPHJP).

[4] Shackleton, C. M. 2015. Non-timber forest products in livelihoods. Pages 12-30 in C. M. Shackleton, A. K. Pandey, and T. Ticktin, editors. The ecological sustainability for non-timber forest products: dynamics and case studies of harvesting. Earthscan, London, UK.

[5] Wiratno. 2014. Strategi dan Kebijakan Pemanfaatan Hasil Hutan Bukan Kayu Dalam Rangka Kelola Kawasan Untuk Kesejahteraan Masyarakat. Yogyakarta (ID) ; Prosiding Seminar Nasional Hasil Hutan Bukan Kayu.

[6] Peraturan Menteri Kehutanan Republik Indonesia Nomor P. 19 / Menhut-II / 2009 Tentang Strategi Pengembangan Hasil Hutan Bukan Kayu Nasional.

[7] Indrasari, D., Wulandari, C., \& Bintoro, A. 2017. Pengembangan Potensi Hasil Hutan Bukan Kayu Oleh Kelompok Sadar Hutan Lestari Wana Agung di Register 22 Way Waya Kabupaten Lampung Tengah. J. Chemical Information and Modeling. 53(9). 1689-1699.

[8] Peraturan Menteri Kehutanan Republik Indonesia Nomor P.21 / Menhut-II / 2009 Tentang Kriteria dan Indikator Penetapan Jenis Hasil Hutan Bukan Kayu Unggulan.

[9] Iskandar. R., Supardi. S., Hasiruddin. M. 2016. Candlenut Efficiency Analysis and Marketing Strategy (Aleurites Mollucana) in Alor Regency. J. ASRJETS. Vol $26101-121.2016$. 
DOI: $\underline{10.51386 / 25815946 / \mathrm{ijsms}-\mathrm{v} 4 \mathrm{i} 3 \mathrm{p} 121}$

Volume: 4 Issue: 3

May to June 2021

www.ijsmsjournal.org

[10] Supriadi, A. et al. 2018. Analytical Hierarchy Process (AHP) Teknik Penentuan Strategi Daya Saing Kerja Bordir. Yogyakarta : Penerbit Deepublish.

[11] Omekwe, Paul S.O., Bosco, Ekpenyong I., Obayori, Bidemi J. "Determinants of Agricultural Output in Nigeria". International Journal of Science and Management Studies. 1 (4) : 65 - 73. 2018.

[12] Saaty, T.L. 2008. Decision making with the analytic hierarchy process. International Journal Services Sciences. I (4) 283-290.

[13] Sari, F. 2018 Metode Dalam Pengambilan Keputusan. Yogyakarta : Penerbit Deepublish.

[14] Dewi, I.S. 2012. Aplikasi Metode AHP - SWOT untuk Perencanaan Strategi Lembaga non Profit. J. Ekonomi Bisnis. Vol II. No. 2. 113-120. Desember 2012. 